\title{
Transposition
}

Musique et Sciences Sociales

1 | 2011

Polyphonie et société

\section{"I Thought It Was Jazz": Polyphonic Voices in Jazz, Modernism, and the Processes of Institutionalization.}

William M. Dabback

\section{(2) OpenEdition \\ Journals}

Electronic version

URL: http://journals.openedition.org/transposition/383

DOI: $10.4000 /$ transposition.383

ISSN: $2110-6134$

Publisher

CRAL - Centre de recherche sur les arts et le langage

\section{Electronic reference}

William M. Dabback, " "I Thought It Was Jazz": Polyphonic Voices in Jazz, Modernism, and the Processes of Institutionalization. », Transposition [Online], 1 | 2011, Online since 01 February 2011 connection on 02 May 2019. URL : http://journals.openedition.org/transposition/383 ; DOI : 10.4000/ transposition.383

This text was automatically generated on 2 May 2019.

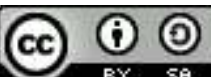

La revue Transposition est mise à disposition selon les termes de la Licence Creative Commons Attribution - Partage dans les Mêmes Conditions 4.0 International. 


\title{
"I Thought It Was Jazz": Polyphonic Voices in Jazz, Modernism, and the Processes of Institutionalization.
}

\author{
William M. Dabback
}

1 The ideology of modernism provides a lens through which we may examine twentiethcentury social systems and artistic movements. Characterized by opposing tensions, modernism promotes the independence and self-location of its artists even as it seeks to mainstream contrary discourses. As artists and movements develop innovative practices, dominant social structures assimilate the new constructs and integrate new ideas. The revised institutions thus provide new boundaries for artists to explore in a cycle of "continuous becoming". Through these processes of institutionalization, the quest for independent voices and the context against which they strive reflect a form of social polyphony.

2 Jazz has reflected modernism's characteristic tensions throughout its existence. Born as utilitarian entertainment, it has since pursued a status as autonomous art. Through 20th century innovations and their resultant discourses, jazz developed a narrative that helped to legitimate its place as art music, sometimes at the expense of its mass entertainment appeal. The assimilation of jazz innovations and the emergence of the jazz "canon" served to extend, organize, categorize, and yet sometimes marginalize its evolutionary movements. This process has often masked the revolutionary natures and discursive interpretations of innovation.

3 This paper examines the movements in jazz in the 1930's and 1940's, and centers on the question of awareness regarding the emergence of bebop out of the Swing Era; the social, musical, and economic realities of the time period; and how these issues relate to concepts in modernism. The study emerged from interviews with five Caucasian men in the Rochester, New York area who were involved with jazz music as performers, collectors, and/or audience members in the United States during the period in question. 


\section{Methodology}

4 This study seeks to present common themes identified through gathered stories and extant research rather than to craft an exhaustive picture of the musical and cultural transitions of the decades in question. Consequently, study participants do not necessarily represent expert opinions; rather, they give voice to various perspectives that range from casual interest as jazz aficionados to insider knowledge as professional artists. Four of the men were identified through their participation in a local Rochester big band program, with which the author worked. Chick (CW) and Robert (RS) were trained musicians who had chosen careers in business and industry, but who played in jazz groups in their youth and off and on throughout their lives. Larry (LF) became an amateur musician late in life but grew up in Rochester with a keen awareness of the jazz scene as a fan and friend of many of the local musicians. Carl P. (CP) was perhaps the most accomplished jazz musician of the four; he grew up playing in big bands and small group settings in the state of New York and the city of Rochester. Together, they offered varying perspectives and opinions that provided themes and color to the study.

5 The fifth interviewee was a Rochester native who formed his first band in 1927 at age 13 and achieved distinction as, arguably, the foremost bandleader in the area. Carl D. (CD) and his band worked out of the Peacock Room in the Hayward Hotel in Rochester during the 1930's and 1940's, and his regular radio program on the local station WHAM was broadcast nationally. His voice contributed a professional's insight to this study as well as the most detailed picture of the Rochester jazz scene.

6 Study members ranged in age from sixty-nine to eighty-nine. Each participated in a semistructured interview regarding his memories and interpretations of the time period; additionally, those who had direct knowledge provided information specifically related to jazz music and post-World War II society in the Rochester, New York area. Interviews yielded seven hours of recorded data. Transcripts were examined for emergent themes, ${ }^{2}$ which were subsequently expanded, supplemented, and reinforced with data from critical and contemporaneous writings to craft an interpretation of the institutionalization processes of jazz.

\section{The Institution of Jazz}

Interviewer: Have you heard of Charlie Parker?

CP: Ah, that was almost like bebop, wasn't it? I don't know. Don't you think so? Kind of? I guess if you want to diagnose bebop - I got a record of the Bird and Diz, yeah. So at the time, I guess. That's probably bebop, I suppose. I thought it was jazz. ${ }^{3}$

7 The above vignette reflects many study participants' unawareness of distinct style periods in jazz during the 1930's and 1940's and indicates how the processes of institutionalization occur over time. Contemporaneous society often did not perceive or understand many of the changes in jazz that seem self-evident in hindsight, including the acceptance of jazz music as an art form. The distinction of periods and styles occurred through complex interactions of public, media, and musicians.

The jazz writer Marshall Stearns claimed that at some point during the 1940's "a battle had been won and jazz had become an accepted sound, if not yet accepted music, in America". ${ }^{4}$ By 1950, portions of the public regarded it as a "native art form to be classed 
with chewing gum, Mickey Mouse, and the skyscraper". ${ }^{5}$ Ostensibly, prior to the 1940 's and the bebop "revolution", the general public viewed jazz and its practitioners as popular entertainments with little status as modern art. A closer examination of its institutionalization offers insights into the apparent paradigmatic shift.

DeVeaux writes that jazz gained enough cultural capital to achieve a position as autonomous art through the construction of a historical narrative ${ }^{6}$ and its discography that formed the "jazz museum". ${ }^{7}$ Canonization holds consensus and assimilation as its central tenets. As the social status of jazz increased, the processes of institutionalization both deemphasized the music's social contexts and marginalized artists and discontinuities that did not align with the dominant, hegemonic view. Bebop, although contemporaneously perceived by some as a radical digression in the 1940's, has since succumbed to the inexorable processes of assimilation in modernism. Labeled and categorized alongside other jazz styles, its innovations have become core elements of modern jazz that inform performance and musical structure, jazz's cultural capital as art music, and its position at the intersection of popular culture and high art. ${ }^{8}$ The institution of jazz now centralizes what was once marginalized.

In much critical discourse and commercial marketing, the jazz tradition appears as a selfevident, objective institution; however, as with all socially created realities, such objectivity only emerges with time. ${ }^{9}$ People experience greater difficulty recognizing and categorizing innovations when they first appear. As in the opening vignette, $\mathrm{CP}$ expressed confusion regarding what historians have identified as a transition from swing to bebop and highlights the constructed nature of the jazz narrative:

According to the historians bebop was a transitional jazz, but I don't know what the hell the difference is. [laughs] I don't really know what the difference is so much. Unless it's Clark Terry and those guys. Or the guy with the bent-up horn there Dizzy Gillespie. Of course, Miles Davis. But [pause], you know, I never did understand what this bebop was... I guess it sounds like jazz. I might be listening to that and thinking it's jazz. Whether it's bebop, I don't know. I could never tell a transition. ${ }^{10}$

11 Likewise, Francis Davis states, "In Charlie Parker's time nobody thought that much about tradition. Jazz music itself wasn't that old. History wasn't a burden in jazz the way it is now." ${ }^{11}$ Henry Mancini played with the Woody Herman band in 1946 and recalls that "nobody had even a remote idea that the age of the big bands was ending." ${ }^{12}$ Feather concurs and believes that it was late 1944 before critics realized that a new genre of jazz was emerging in the form of bebop. ${ }^{13}$ Categorizations and labels satisfy the human need for explanation; however, their creation can often only occur in retrospection. As a result, jazz is now generally perceived to have moved through a succession of periods or styles, each with a "conveniently distinctive label and time period". ${ }^{14}$ While this metanarrative serves a need for historical explanation, it tends to obfuscate a polyphonic milieu - the simultaneous existence of diverse jazz styles and the competing forces involved in innovative practices.

Labeling a period does not negate the existence of multiple musical styles. For example, even as the new jazz ethos was emerging a few hundred miles across the state in New York City, the Rochester, New York scene in the 1940's was still firmly in the grip of the sweet band culture and economics. As in 1930's New York City, Rochester sweet bands enjoyed the economically lucrative benefits of commercial music; ; ${ }^{15}$ people paid to hear music that featured little improvisation, an emphasis on popular melodies, crooners and, often, string instruments. ${ }^{16} \mathrm{CD}$ was a bandleader centered in Rochester for much of the 
1930's, 1940's, and beyond, and many considered him to be its foremost practitioner. His memories of the Peacock Room support the influence and commercial value of sweet band music:

CD: It started right at Clinton and Main Street. And right on the corner was the Peacock Room. And it was Fred Odenbach's Peacock Room. Fred owned that property right around where Chase Bank is today. And I played in there for Fred Odenbach for, oh God, from way back in 1931. But it wasn't my band, you know. Eventually it became my band. I went in there in 1940, I think it was, and I organized a six-piece band. In those days, in those hotels, there was a depression going on. And I had a violin, tenor sax, harp, girl harpist - I was the only one to use a harpist around Rochester - piano, string bass, and drums. We stayed there until 1947 I think they closed. They loved our dinner hour 'cause I had the violin, and we'd play semi-classical stuff so when you eat, you can enjoy it. ${ }^{17}$

CD also referred to an abundance of diverse venues that attests to a thriving entertainment industry that featured simultaneity of styles:

Going south, on south Clinton Avenue, we had the Peacock Room, which is the Hotel Hayward. And then after that was the Temple Theatre, and they had dance bands. I met Lawrence Welk in there, and Charlie Spivak - all the bands that came through. They brought the big name bands in there. And then there was little theater a little farther south called the Victoria Theatre. There was one place over on Broad Street, the next street down, called the Rustic Garden. That was down in the basement, and they had just mediocre local bands in there. And then you go back to Clinton Avenue, and there was a place called Stony's Nut Club. It was a kind of a way "knocked out" nightclub. And you jumped up to where Geva is today. Geva used to be called Convention Hall. And that's before the Eastman Theater was built. That's way back in the early ' 20 's. And they brought in all the famous classical singers. That was the Eastman Theater of Rochester back in the '20's. Up until ' 22 or '23 when they started to build the Eastman. And we go back and start at Clinton Avenue again, on the east side of Clinton Avenue. We went all the way up the west side. On the left-hand side, you had the Hotel Seneca, and the Lyceum Theatre, which brought in the best in actors - plays and stuff like that. John Barrymore and all the leading stars would come through the Lyceum. In fact, they brought Sigmund Romberg, a dear friend of mine [...] Then they had a ballroom, called the Arcadia Ballroom, which they danced five, six nights a week. And they used to bring in little road bands. Nine, ten, fifteen, twelve pieces like Abe Spagode. They had a band from Buffalo. A black band called Captain [name obscured] and His Algerians. I don't think any of the guys could read music, but they played loud! They'd just have one band at that place. It was a dime a dance, I think. That was one of the places that very few people remember. It was right where Wegman's Store used to be. And on the other side they built the Loews Theatre. That was a big deal. Xerox had a little nightclub up there. Down in their basement. They had a theater upstairs. They were going to be a big deal. ${ }^{18}$

The simultaneity of styles in Rochester and elsewhere raises questions with regard to jazz canonization. On a national level, Lawrence Welk had a very popular variety show that featured sweet band arrangements through the early 1980's. Indeed, popular big bands still exist today in the form of ghost bands long after the passing of their founders and the Big Band era. Alternatively, historical narratives generally confine major figures such as Count Basie, Benny Carter, and Coleman Hawkins to the swing genre despite the many recordings they made with bebop artists. While their performance practices may have slightly differed, on some level they expressed an obvious acceptance and alignment with the newly formed jazz ethos in the 1940's and 1950's. These deviations from the institutionalized historical narrative suggest a need to reconceptualize the "new" 
replacing the "old" when discussing the jazz tradition. Despite the modernistic process of assimilation, the degrees of freedom embedded within institutionalized structures in fact allow for a multiplicity of styles and lead to questions regarding processes of innovation.

\section{Revolution/Evolution}

Interviewer: Looking back, do you see jazz as being something that is continuous or were there different types of jazz that you were aware of at that time?

CW: At that time, I was probably not particularly aware. You know, I was just doin' my thing. Clearly it is continuous with some obvious [bumps] here and there. But it evolves like anything else. ${ }^{19}$

Musical genre clearly changes over time; however, $\mathrm{CW}$, like other study participants, lacked conscious awareness of the transitions in jazz during the middle of the 20th century. In retrospect, he generally perceives continuous change but with some interruptions. Do innovations in art explode in revolution against existing practices or do they evolve gradually in a kaleidoscopic cycle? Examiners with a social/political lens generally embrace the former, while music scholars have espoused the latter perspective in the development of art canons. ${ }^{20}$ Depending on the research lens, one may justify either perspective or even an amalgamation of the two. It seems apparent, however, that certain seminal points in the historical context of jazz have had appreciable impacts on both its culture and its music. The emergence of bebop out of the Swing Era marks one such revolution/evolution in the jazz timeline.

Jazz's search for new artistic expressions creates tension with its function as dance music, which leads to a constant fluctuation regarding the music's relationship to mass audiences. ${ }^{21}$ Gendron lists some of the dichotomies inherent in this tension as artcommerce, authenticity-artificiality, swing-jazz, European-native, folk culture-refined, technique-affect, modern-traditional, black-white, fascism-communism, and right wingleft wing. ${ }^{22}$ DeVeaux believes that jazz became art music through crisis arising from the manifestation of these tensions. In his view, capitalism and the commodification of music created an impasse for certain artists and ideas until the building pressure erupted into a new jazz ethos in bebop and its separation from commercial interests. ${ }^{23}$

17 A more evolutionary perspective of the bebop movement identifies the resultant jazz ethos as a natural extension of the modernist swing ethos. ${ }^{24}$ The central argument for this perspective emphasizes how bebop pioneers spent their formative years fully ensconced in the swing tradition. Early jam sessions comprised small group swing, and stylistic modifications came gradually - possibly with no real intent of "changing" the music. The jazz concert format was in existence during the reign of the big bands and marked a wide consciousness of jazz as an art form, despite its primary function as entertainment for mass audiences. ${ }^{25}$ Additionally, the recording ban in the early 1940's resulted in a missing discographic link between swing and bebop, which exaggerated the differences of the latter in the public ear. Combined, these factors point to bop as an outgrowth of the existing swing practices rather than a radical digression from them and mark "the stage at which jazz completed its transformation from entertainment into art" [emphasis added]. ${ }^{26}$ Regardless of revolution or evolution labels, what forces then propelled this transformation? 


\section{Media, Labels, and Meanings}

LF: I don't think it was right. They didn't get the recognition, some of these guys. They were great. Like Charlie "Bird" Parker, like Dexter Gordon. Those guys were good - they were really good! They made rules for the black guy. Then they didn't give them the publicity, take their picture, put it in magazines, and all that. They didn't do that with the black people. That's where they was discriminated against. ${ }^{27}$

Media plays an integral role in the acceptance of musical styles and its practitioners. As LF astutely notes in the above quote, media can also erect barriers that prevent artists from gaining the commercial success that peers enjoy. Race and discrimination played vital roles in how bebop was received in the United States; however, a culture of celebrity and media labels that sometimes brought negative connotations also significantly affected reception.

Jazz saturated the American music market during the third and fourth decades of the twentieth century largely through advancements in technology and the maturation of jazz music criticism. Study interviewees' earliest memories were grounded in recordings of big bands of the 1930's such as Glenn Miller, Tommy and Jimmy Dorsey, Benny Goodman, and Artie Shaw. Guy Lombardo's group was cited as a favorite sweet band. Not all participants had early memories of black bands, but Horace and Fletcher Henderson, Don Redman, and Duke Ellington all received mention. Exposure to all of these groups came through communication and recording technologies. Growing up in Rochester, one participant remembered hearing radio broadcasts:

CD: I knew all the bands. You could always turn the radio on and get a big band out of New York or Chicago. I started to pick up the radio stuff around 1930, '31. ${ }^{28}$

Another was a collector of recordings:

CP: I got 78's. I got about two hundred fifty 78's [from the 1930's and 1940's]. ${ }^{29}$

And a third remembered the first record he bought:

Interviewer: Do you remember the first jazz record that you bought?

LF: [pause] Oh, in our day? No. I, I don't remember. [pause] Yeah, ah, come to think of it - Oh, ah, Coleman Hawkins, Body and Soul! Yeah, yeah, I remember; I was in the back of my father's shoe repair store [when a friend told him about the record]. 30

Radio and records facilitated mass distribution of music and gained notoriety for musicians, which resulted in economic reward and, consequently, a degree of freedom for artists to experiment in the recording studio.

Jazz criticism, still in its infancy during the 1930's and 1940's, consisted primarily of superficial record reviews found in enthusiasts' magazines outside of academia, although the writings of John Hammond and others who addressed civil rights, economic, and cultural esteem issues contained the seeds of more critical substance. ${ }^{31}$ Despite the often extreme partisanship on the part of writers, many musicians such as Ellington understood critics as necessary for the elevation of the perception of jazz as art. ${ }^{32}$ However, artists ultimately had little control over the discourses that directly impacted public meaning-making. ${ }^{33}$ Recording industry corporations and media critics often forced labels upon the music, thereby contextualizing artistic free-will with a deterministic approach. This imbalance of power underscored the inherent "agentic asymmetry" ${ }^{34}$ of the music industry, in which individual agency was not equal to the social structures within which it functioned and resulted in the privileging of a cult of personality, the 
subjective labeling of artistic works and movements, and even explicit discriminatory practices.

\section{A Cult of Personality}

24 The identification of jazz with specific personalities reflects the commodification of the music and stands in opposition to the modernist pursuit of a commercialism-free art. The media promoted a cult of personality and, in so doing, often masked the underlying social stratifications and systems that legitimated inequalities. One study participant remembered an incident that emphasized the privileged position of a well-known swing drummer:

CP: I heard Artie Shaw in 1940. Buddy Rich had just gone with him [laughs]. Shaw drove, Shaw's band came in a bus, and Buddy Rich showed up in a sports car with "Buddy Rich the World's Greatest Drummer" printed on the side of the sports car! [laughs]..$^{35}$

25 As a prominent bandleader, $\mathrm{CD}$ emphasized the importance of public image for musicians of the era:

CD: I always went out to say hello to people in the audience, you know, when [I had] time off from the bandstand.

Interviewer: So the personality is just as important as the music?

CD: That's right. I used to be a pretty sharp dresser! But clothes meant a lot. I used to wear spats, and a shirt that the stripes, instead of going down, went across, and a starched collar - one of those stiff collars, you know? And boy, when you got up on the bandstand, they all looked at you. They didn't look at the music! ${ }^{36}$

While the garnering of good press constituted an economic necessity for a jazz musician, as early as 1950, Reddick reflected that the media emphasis on personality rather than artistry in bebop led to mediocre imitators who ultimately cheapened the music. He stated, "The rise and fall of Be-bop is but another demonstration of the death grip that commercialism has on popular culture." ${ }^{37}$

\section{Media Labels}

The superimposition of meanings and labels on jazz music has led to controversy through much of its existence. Some writers view the term "jazz" itself as problematic. Porter points out the inadequacy of a single term to describe all styles and genres categorized under the name, although he acknowledges its usefulness as shorthand to reference the processes through which musicians have been socially and economically situated. ${ }^{38} \mathrm{He}$ cites a second problem as the derogatory connotations sometimes attached to the label a perspective shared by Miles Davis, who claimed, "I don't like the word [jazz] because the record companies don't push it when it's called that, because white people want to protect their daughters' asses." ${ }^{39}$

28 As a label, "bebop" came into vogue beyond the purview of musicians. Kenny Clarke states,

'Bebop' was a label that certain journalists later gave it, but we never labeled the music. It was just modern music, we would call it. We wouldn't call it anything, really, just music. ${ }^{40}$

29 "Bebop" conjured directly negative associations. Created by the media, society infused the term with meanings of an aberrant lifestyle and radical political connotations that 
encompassed clothing, drug abuse, and even "the fad among Negroes for adopting Mohammedan names". ${ }^{41}$ Charlie Ventura expressed his reluctance to market his music under "bop":

But the average laymen, or the average listener, they thought bop was only associated with people that were on drugs, and goatees, and this, and led a dirty life and that they would gear their children to stay away from the beboppers, nothing but a bunch of hopheads. ${ }^{42}$

Media labels focused attention away from musical innovations and toward social stigmas that did not necessarily reflect the general culture of bebop; consequently, both critical and popular music venues marginalized the music.

\section{Discriminatory Practices}

31 The confining of black musicians to specific recording categorizations in the 1930's reflects issues of discrimination related to the labeling of jazz styles. Although media offered full critical coverage of "hot" jazz by 1935 and Readers' Polls during that time indicate a perceived increased status of black musicians, ${ }^{43}$ DeVeaux demonstrates how racial discrimination in radio and the movies limited the media coverage of black jazz musicians. These constraints forced musicians to rely on recordings for exposure and restricted their media appearances to stylistic mediums that record executives deemed as racially authentic..$^{44}$ Alternatively, contemporaneous media ostensibly authenticated music of white musicians through the endorsements of black musicians, as in bandleader biopics in which artists such as Louis Armstrong and Fletcher Henderson were asked to affirm the music of Glenn Miller and Benny Goodman. ${ }^{45}$

Despite ideals of swing music as a democratic art, segregation and economic discrimination remained the norm throughout the era of big bands. Dalfiume writes that in 1942, on a macro-societal level, "after two years of militant agitation by Negroes, six out of ten white Americans felt that black Americans were satisfied with things the way they were and that Negroes were receiving all of the opportunities they deserved." ${ }^{46}$ One may argue that it was this inability to alter the social and economic institutions in jazz that led to a self-conscious attempt by black musicians to find a new point of engagement with the music industry.

The search for equality outside of the hegemonic structures of the Swing Era aligns with modernist conceptions of an autonomous art. Although jazz sought to straddle both the entertainment and art worlds, bebop segregated itself from the former through the creation of an "artistically self-conscious listening music" 47 that disengaged from more socially responsive aspects. Ironically, although "blackness" offered a guarantee of cultural authenticity in bebop, in becoming "art", jazz lost its African-American exclusivity ${ }^{48}$ which resulted in a paradox of legitimacy. This paradox leads to a second issue related to perceptions of race and culture. If bebop is art in the context of a historical jazz tradition, then all jazz must be art in retrospect. ${ }^{49}$ Finally, the problem of autonomous art as it relates to racial discrimination offers a third issue according to Stearns:

Jazz is a potent force in debunking the myths of Fine Art and the social pretensions of the concert Hall. To allow that jazz should be granted a role in the world of art leads to disconcerting questions about who is really cultured in our society, and to admit that a persecuted minority is able to produce a real art is to imply that the

Transposition, 1 | 2011 
individuals in this group are gifted enough to play a more important part than that of second-class citizens. ${ }^{50}$

\section{Autonomy versus Commercialism}

CD: If you want to make a living [in jazz], you've gotta stay realistic. ${ }^{51}$

merit does not necessarily translate to economic benefit. One of the secrets to CD's longevity and success as a bandleader was his pragmatism regarding popular tastes and commercial interests. Jazz artists have not always embraced the modernist disregard for audiences and economic advancement while seeking self-determination and status. Bebop promoted avant-garde concepts and techniques in its pursuit of artistic freedom and the challenging of audience preconceptions, but in hindsight it seems that one of the ultimate goals of its practitioners was a new engagement with the social and economic system against which they were rebelling.

The tensions patent between the modern institution of jazz and the bebop revolution/ evolution emerged from the dichotomy of artistic autonomy and the influence of commercialism. The development of a new ethos in the 1940's challenged audiences with unfamiliar sounds and an elitist music that demanded specialized knowledges. While the new practices ultimately offered a source of artistic integrity for musicians, many listeners found themselves puzzled and even alienated by the developments. Artists faced a discrepancy between their artistic ideals and their economic need for commercial support.

\section{An Elite Music}

Contemporaneous accounts of bebop music describe it as "screechingly loud" and "breathlessly fast, with some biting dissonance and shifty rhythms". ${ }^{52}$ The centrality of improvisation also discomforted audiences used to more recognizable, and perhaps repetitious, riffs and melodic structures. RS experienced musical transitions in jazz as a young amateur musician. Although he did not know the theory behind the sounds, he knew that the group had crossed a significant threshold:

RS: The group was rather exceptional and I've always wished that I could remember the name of the leader because all the music was manuscript. And he was arranging it all. And it was my first real taste of real modern chords. I hear the words diminished seventh and so forth [laughing] but I don't really know what it means. I just sorta know when I hear them that that's not a, you know, that it's not a Dixieland kind of chord. That it's just something very different, almost atonal sometimes, but not really. ${ }^{53}$

The emergence of new theoretical languages and techniques increased the demands on post-bebop generations of musicians and listeners. Throughout the Swing Era, white musicians generally had the advantage of better music educations. ${ }^{54}$ LF certainly supported this perception:

LF: You know who was really good was Harry James. Harry James and Charlie Spivak. Those guys were - they were educated musicians! ... Woody Herman, I think he was an educated musician..$^{55}$

Charoenying maintains that bop musicians were better educated than their swing predecessors and made use of their formal knowledge to intellectualize the music. ${ }^{56}$ The resulting specialized musical language and practices contained within a closed system 
accessible only to insiders also facilitated the alienation of its artists from the mainstream musical society and industry. As part of the Rochester musical mainstream, CD viewed such experimentation and its practitioners with skepticism, including the physical locations of their interactions:

CD: [On jam sessions] They did a few of these joints, you know? Real crummy spots. There was a joint out on West Main Street called the Blue Front. And the guys used to come in there after hours and jam. I didn't care for that bunch of people. I mean, I liked good jazz, if they were good. ${ }^{57}$

Beyond the cultural distance, study interviewees expressed their discomfort with and alienation from modern jazz through comments about its musical content. One of their primary concerns was the perceived lack of melodic content:

CD: There was Dizzy Gillespie, and, uh, who the hell was that alto sax player [long pause] Interviewer: Charlie Parker?

CD: Charlie Parker. And they used to work around New York City a lot. And they'd go into these nightclubs. All they are is a hole in the wall and a piano. And they'd start seeing how far away from the melody they could get. Some of them, I don't think, ever got back! $!^{58}$

CP: [Bebop players] moved around a lot. They got a little away from the melody, I think. I mean, [sings "Just Friends"] "Just Friends", or something like that - you can hear the melody, but [pause] I think, really, I enjoyed the big band stuff better because it was more structured. They do have solos in it, but it's structured. ${ }^{59}$

Tastes in improvisation reflected similar preferences:

CD: [Discussing improvisation] I'm a funny guy. I like a certain way they played, or I don't. They either played good or they don't, you know?

Interviewer: What did you consider "playing good?"

CD: Well, that's when you ad lib. You play the right chord changes. 'Cause if you don't play the right chord changes, and you start poopin' all over the place, it's just a lot of noise..$^{00}$

CP: I gotta have a tune, I think, to start with, that's the way I feel about it. And I think some of the stuff that now - What they're doin' now [is] a lot of mechanism. I like being able to hear a tune. ${ }^{61}$

41 In a famous quote, Louis Armstrong connected similar sentiments to the more practical, economic ramifications of bop as he saw them at the time:

First people get curious about it just because it's new, but soon they get tired of it because it's really no good and you got no melody to remember and no beat to dance to. So they're all poor again and nobody is working, and that's what that modern malice done for you. ${ }^{62}$

The elitism of bebop as a "player's music" in part led to the acceptance of jazz as an art form; its artistic isolation provided cultural force and value. It espoused a calculated hostility toward earlier styles and challenged jazz's democratic ethos with the importance of improvisation in a soloists' music; ${ }^{63}$ however, its purist aesthetic ideals simultaneously estranged many in the jazz audience and industry and seemingly sacrificed its utilitarian entertainment value. ${ }^{64}$

\section{Commercial Interests}

Most of American society experienced economic hardship in the 1940's. World War II affected many musicians and exacerbated the difficulties of making a living as a musician regardless of musical style. $\mathrm{CD}$ related how taxes negatively impacted his time at the 
Peacock Room, speculating that the capacity audiences the club enjoyed were severely curtailed because of the additional burden:

CD: When the war started out, about 1944, they put a tax on entertainment. And it was a thirty percent tax. And you'd come in, and if there was any entertainment or dancing in the room, you'd get smacked thirty percent. A week after that [pause and a sigh]. We used to have capacity audiences. ${ }^{65}$

$\mathrm{CD}$ also alluded to the difficulty and expense of running a big band, perhaps speculating on the changing economics in jazz yet still embracing the commercial value of utilitarian music. He perceived that the emphasis on concert rather than dance music along with the expense of a large ensemble led to the demise of a friend's touring band:

CD: [Addressing a friend who went on tour with a 22 piece band] "I'll give you two and a half years", I says. "You'll come back bankrupt". I got it almost to the day. You can't afford it! Twenty-two pieces, you go into a small town, they wouldn't have any big audience. People wouldn't understand the big band, you know? They had a good dance book, but when they did the stage show it was all these fancy arrangements. ${ }^{66}$

Jazz has always engaged in a dichotomous relationship with commercial interests. In its pursuit of an institutionalized status, jazz demonized the commercial system, which added to the cultural capital of the music. ${ }^{67}$ Consequently, jazz criticism has relentlessly accentuated the corrupting influence of the marketplace. Early critics made continual references to the "commercial capitulation of swing musicians", ${ }^{68}$ and proselytized that artistic progress only occurs in the absence of marketplace influences. Even with its radical connotations, companies tapped bebop for its potential for profit in the late 1940's although they often dictated what artists would record:

Charlie Ventura: The major companies like Coral and Decca, RCA Victor, and Columbia, they would dictate what they wanted, and if you were on a recording session you had to play [seven out of eight songs for them]. ${ }^{69}$

In the apparent modernist paradox, while artistic autonomy holds value, canons of art almost exclusively comprise critically and/or commercially viable pieces. Although outside institutions such as government or patrons may buffer this phenomenon, works must still be reified, if not commodified, for the institution of jazz to grant significance. Therefore, while the jazz ethos embraced by bop artists potentially equated swing with commercialism, an alternative perception views swing music as a fortunate confluence of mass popular tastes and jazz history that resulted in an aberration of a jazz music that was not culturally marginalized. ${ }^{70}$

Tensions run between autonomy and commercialism and the blurred lines that swing and bebop tread through their concert settings, dance functions, and jam sessions. Although swing largely served as dance music, it created an audience that willingly attended to the music for its own merits. The division in audiences between "listeners" and "dancers" was not strict, and many attendees alternated activities. ${ }^{71}$ People who desired to listen as well as dance facilitated the emergence of the jazz concert, with its higher social and cultural connotations, ${ }^{72}$ supported by statements from interviewees:

LF: I went [to the dances] because of the bands... I can't tell you that I had much experience in dancing, but I used to go just to see the bands. ${ }^{73}$

Interviewer: When you went to see a big band, did you go to dance or to listen?

$\mathrm{CP}$ : Nope, climbed up on a roof to listen. Whatever we could hear, yeah. That's in the 30's I'm talking about. No, we didn't go [to dance] - we just went to hear 'em. [...] In Binghamton. George F. Johnson started Endicott Johnson. He's gone now, but he built parks and this amphitheater, with a casino or some damn thing. They had 
music. Big bands came in every Friday night, so we, we heard a lot of those. That was where we heard Shaw. [laughs]

Interviewer: And they just came in and played concerts?

CP: They just played concerts. We just sat there. Oh, maybe somebody was dancin' out back, but people sat there, just like if you look at pictures of Goodman playin'. There's a huge mass of [people]. They're just standin' there! Of course, sometimes if you got Helen Forrest for a vocalist. Like with Kenton, if he's got Julie London, people are lookin' at them, oglin' the girl vocalist. ${ }^{74}$

Many Rochester establishments drew both famous musicians and local talents who provided jazz concert experiences:

$\mathrm{CP}:[\mathrm{I}]$ saw Goodman at the Eastman - small group there. ${ }^{75}$

LF: Jazz concert? Yeah, we used to have a lot of those guys come over at the Temple Theater. Not to dance, though. I think Chuck Barone participated - I forgot which band it was. It might have been the Blue Baron thing, I forgot. Yeah, I used to go to all those bands. I remember Billy Pointer's band. He started a band in our neighborhood. And it was good, it was good. I remember Glenn Miller came here. I was, ah, 19 - just before I went into the Navy, so [it] must've been 1942. And three guys - we were always together - we go to see Glenn Miller at the marina, near Lake Avenue. The three of us [also] decided to go to New York City and see Frank Sinatra. And that was 1943 - November '43. Can you imagine? 60 years ago, and I'm here to tell it. Whenever we had these big bands coming over I used to go to them like I told you. It was at the Stardust. It's right near Phelps Street off of Lake Avenue. Recreation center. ${ }^{76}$

Conversely, although study participants did not share anecdotes, many writers attest that bebop sometimes functioned as music for dancing. ${ }^{77}$

The jam session laid the foundation for the new jazz ethos of bebop with its own closed structured procedures, hierarchies, and knowledges that raised the performance standards of its musicians; however, the swing industry provided the economic foundation upon which informal session-playing rested. ${ }^{78}$ Additionally, opportunities for engagement with the commercial market beyond the recording studio developed in the 1940's, specifically in the form of Norman Granz's 1944-1946 concert series of "public" jam sessions in the Los Angeles Philharmonic Auditorium. "Jazz at the Philharmonic", as it came to be called, evolved into a nationwide tour featuring top jazz musicians in which the competitive aspects of jam sessions were underscored, thereby tapping into the public excitement that big band soloists had generated. With relatively low overhead, the tour became an economically efficient format that served to introduce many bebop artists to broader audiences. ${ }^{79}$ These blurred lines between autonomy and commercialism again underscore the necessity of social and economic advancement for artistic achievement and how bop musicians searched not for disengagement, but rather for a new engagement with the commercial world.

The intersection of bop and big band in the 1940's reflects polyphonic tensions in the simultaneity of styles, the assimilation of bebop principles in jazz, and the challenges of balancing artistic innovation with commercial demands. Buddy DeFranco stated that "every big band had its group of us that were gravitating towards the modern jazz area." ${ }^{80}$ In 1950, Stearns was more pessimistic, claiming, "the clichés of Bop, watered down almost past recognition, are beginning to appear in the arrangements of dance bands all over the country." ${ }^{81}$ Woody Herman willingly incorporated the new concepts as the first person to pay Dizzy Gillespie "a hundred dollars" for an arrangement..$^{82}$ In 1946, the Herman band was demonstrating the commercial viability of modern big-band jazz, ${ }^{83}$ and 
by 1947 had fully embraced the bebop influence even as it retained some swing material in its book. ${ }^{84}$ According to Herman, this evolution presented difficulties:

I felt that what I did was the right thing to do at that point, but I was on shaky ground, I felt, very often during that period. The general public wanted a carbon copy of what they'd heard before... and they felt that I was blowing it. ${ }^{85}$

Other leaders found difficulty in assimilating bebop concepts and finding commercial success. Boyd Raeburn recorded "Night in Tunisia" with Dizzy Gillespie, but two of his sidemen discuss how he was denied other opportunities:

Frankie Cocolow: It [Raeburn's band] was less commercial than any band I had been with." ${ }^{86}$

David Allyn: It's a shame. If the band had been accepted a little more - record-wise, appearance-wise - I think we would have perhaps come right up to make some records that - I say record-wise meaning if we were accepted in the record business. ${ }^{87}$

53 Lee Konitz states that in the 1947 Claude Thornhill band, "Gil [Evans] was, in fact, teaching the men how to play bebop... That was the music." 88 One interview participant remembered the Thornhill band's economic success did not match its artistic achievements:

$\mathrm{CP}$ : Loved him. He had tremendous arrangements with six or eight clarinets, a lot of stuff you know. He had that one - "Life On a Guinea Farm." Crazy stuff, you know?... It was more concert music than dance music. That's why he never went over, you know. The only kinda hit he had was the "Sunday Kind of Love." 89

\section{Conclusion} must function within the social systems in which they exist. Despite its mass appeal and commercial interests, the swing industry provided early bebop musicians with enough stability to make a living, a musical language and history on which to build, and the freedom to engage with like-minded others in jam sessions and dialogues that furthered their experimentation. Many big bands had already blurred the lines between utilitarian 
dance music and artistic concert settings; however, the new ethos promoted musical autonomy divorced from popular appeal. In the pursuit of their artistic ideals, musicians developed new techniques and expanded the musical vocabulary of jazz. These advances and the apparent rejection of commercial considerations helped to elevate the institution of jazz as art. In doing so, bebop musicians provoked questions of artistic legitimacy and discrimination that remain topics of discourse to this day.

In this study, the pursuit of an autonomous art and its dialectical relationship with commercialism provided a point of departure for discussion of the processes of institutionalization and a discussion of its effects in the particular context of Rochester, New York. Because of the complex social systems involved, institutions resist significant change. Bebop musicians risked economic and social alienation even as they developed the cultural capital to raise the level of jazz discourse. They resisted the commodification of jazz music to move beyond the bounds of the swing industry paradigm to create both an elite music and a new point of engagement with the music industry. In doing so, they explored the boundaries of the jazz institution, and, after that same institution assimilated bebop's innovations, provided new boundaries that future musicians would explore in the cycle of continuous becoming.

\section{BIBLIOGRAPHY}

ANDREWS, John, “What bebop meant to jazz history”, in World Socialist Web Site, 1998, http:// www.wsws.org/arts/1998/may19..., Accessed 8/7/08.

BARAKA, Amiri, “Jazz and the white critic", in WALSER, Robert (ed.), Keeping Time: Readings in Jazz History, New York, Oxford University Press, 1999, p. 255-261.

BERGER, Peter L., LUCKMANN, Thomas, The Social Construction of Reality, New York, Doubleday, 1966.

BOYER, Richard O., "Profiles: Bop", in The New Yorker, 24, 1948, p. 28-32.

BUCKNER, Reginald T., WEILAND, Steven (ed.), Jazz in Mind: Essays on the History and Meanings of Jazz, Detroit, Wayne State University Press, 1991.

CHAROENYING, Timothy, "Jazz at the Crossroads", in The Atlantic Online, 2003, http:// www.theatlantic.com/unbound/..., accessed 9/30/08.

DALFIUME, Richard M., “The forgotten years of the negro revolution”, in SCHEINER, Seth M., EDELSTEIN, Tilden G. (ed.), The Black Americans: Interpretive Readings, New York, Holt, Rinehart and Winston, 1971, p. 420-436.

DANNEFER, Dale, “Freedom isn't free: Power, alienation and the consequences of action", in BRANDTSTADTER, Jochen, LERNER, Richard M. (ed.), Action and Self-development: Theory and Research Through the Life Span, Thousand Oaks, Sage, 1999, p. 105-132.

DAVIS, Francis, Bebop and Nothingness, New York, Schirmer Books, 1996. 
DAVIS, Francis, Outcats: Jazz Composers, Instrumentalists, and Singers, New York, Oxford University Press, 1990.

DEVEAUX, Scott, The Birth of Bebop: A Social and Musical History, Berkeley, University of California Press, 1997.

DEVEAUX, Scott, “Constructing the Jazz Tradition: Jazz Historiography”, in Black American Literature Forum, 25, N³, 1991, p. 525-560.

DEVEAUX, Scott, "Introduction / The emergence of the jazz concert, 1935-1945", in American Music, 7, 1989, p. 6-29.

FEATHER, Leonard, Inside Jazz, New York, Da Capo Press, 1977.

FEATHER, Leonard, From Satchmo to Miles, London, Quartet Books, 1974.

GABBARD, Krin (ed.), Jazz Among the Discourses, Durham, Duke University Press, 1995.

GENDRON, Bernard, “Moldy figs and modernists: Jazz at war (1942-1946)”, in GABBARD, Krin (ed.), Jazz Among the Discourses, Durham, Duke University Press, 1995, p. 31-56.

GENNARI, John, "Jazz criticism: Its development and ideologies", in Black American Literature Forum, 25, N³, 1991, p. 449-523.

GITLER, Ira, Swing to Bop: An Oral History of the Transition in Jazz in the 1940's, New York, Oxford University Press, 1985.

HARVEY, Mark S., "Jazz and modernism: Changing conceptions of innovation and tradition", in BUCKNER, Reginald T., WEILAND, Steven (ed.), Jazz in Mind: Essays on the History and Meanings of Jazz, Detroit, Wayne State University Press, 1991, p. 128-147.

HORE, Charlie, “Jazz - a people's music?”, in International Socialism Journal, 61, 1993, http:// pubs.socialistreviewindex.or..., Accessed 6/14/10.

“How deaf can you get?", in Time, 51, 1948, p. 74.

INTERVIEWS, Five participants: RS 11/06, LF 11/08, CP 11/11, CW 11/13, CD 11/30, 2003.

LEES, Gene, Leader of the Band: The Life of Woody Herman, New York, Oxford University Press, 1995. LOPES, Paul, The Rise of a Jazz Art World, Cambridge, Cambridge University Press, 2002.

LOTT, Eric, “Double V, Double-Time: Bebop's politics of style”, in Callaloo, 36, 1988, p. 597-605.

MERRIAM, Sharan B., Qualitative Research and Case Study Applications in Education, San Francisco, Jossey-Bass, 1998.

OWENS, Thomas, Bebop: The Music and Its Players, New York, Oxford University Press, 1995. PORTER, Eric, What Is This Thing Called Jazz?, Los Angeles, University of California Press, 2002. REDDICK, Lawrence Dunbar, “Book review: Inside be-bop”, Phylon (1940-1956), 11, N¹, 1950, p. 99. STEARNS, Marshall Winslow, “Rebop, bebop, and bop”, in Harper's, 200, 1950, p. 89-96.

STEPHENSON, Wen, “A conversation with Francis Davis”, in The Atlantic Online, 1996, http:// www.theatlantic.com/unbound/..., Accessed 11/30/08.

TOWNSEND, Peter, Jazz in American Culture, Jackson, University Press of Mississippi, 2000. 


\section{APPENDIXES}

\section{Appendix A - JAZZ AND MODERNISM INTERVIEW GUIDE}

\section{General}

1.Where did you grow up? Were you in the Rochester area in the 1940's and 50's?

2. Tell me about your earliest memories and experiences in jazz.

3. What was the first jazz record you bought?

4. Where and when did you first hear live jazz?

5. Have you ever gone to a nightclub to hear jazz? When? Where?

6. Who were your favorite artists? Why?

7. Give a brief comment for each of the following names: Woody Herman, Boyd Raeburn, Claude Thornhill, Charlie Parker, Dizzy Gillespie, Thelonius Monk.

\section{Rochester-Specific}

8. Were there dance halls in or around Rochester? Did you go to them? Were they racially integrated? Were the bands both black and white or just one or the other?

9. What nightclubs were around? Describe the jazz "scene."

10. What bands played around the Rochester area? Who were the "star" musicians?

\section{NOTES}

1. GENNARI, John, "Jazz criticism: Its development and ideologies", in Black American Literature Forum, 25, № 3, 1991, p. 449-523.

2. MERRIAM, Sharan B., Qualitative Research and Case Study Applications in Education, San Francisco, Jossey-Bass, 1998.

3. Interview with CP, November 11, 2003.

4. STREARNS, Marshall W., "Rebop, bebop, and bop", in Harper's, 200, 1950, p. 89.

5. STEARNS, Marshall W., op. cit., p. 89.

6. DEVEAUX, Scott, "Constructing the Jazz Tradition: Jazz Historiography", in Black American Literature Forum, 25, N³, 1991, p. 525-560.

7. DEVEAUX, Scott, The Birth of Bebop: A Social and Musical History, Berkeley, University of California Press, 1997.

8. PORTER, Eric, What Is This Thing Called Jazz?, Los Angeles, University of California Press, 2002.

9. BERGER, Peter L., LUCKMANN, Thomas, The Social Construction of Reality, New York, Doubleday, 1966.

10. Interview with $\mathrm{CP}$. 
11. STEPHENSON, Wen, “A conversation with Francis Davis", in The Atlantic Online, 1996, http:// www.theatlantic.com/unbound/..., Accessed 11/30/08 .

12. LEES, Gene, The Leader of the Band: The Life of Woody Herman, New York, Oxford University Press, 1995, p. 138.

13. FEATHER, Leonard, Inside Jazz, New York, Da Capo Press, 1977.

14. DEVEAUX, Scott, "Constructing the jazz tradition: Jazz Historiography", in Black American Literature Forum, 25, № 3, 1991, p. 525.

15. LOPES, Paul, The Rise of a Jazz Art World, Cambridge, Cambridge University Press, 2002.

16. TOWNSEND, Peter, Jazz in American Culture, Jackson, University Press of Mississippi, 2000.

17. Interview with CD, November 30, 2003.

18. Interview with $C D$.

19. Interview with CW, November 13, 2003.

20. DEVEAUX, Scott, The Birth of Bebop: A Social and Musical History, Berkeley, University of California Press, 1997.

21. HORE, Charlie, "Jazz - A people's music?" in International Socialism Journal, 61, http:// pubs.socialistreviewindex.or..., Accessed 6/14/10, 1993.

22. GENDRON, Bernard, "Moldy figs and modernists: Jazz at war (1942-1946)", in GABBARD, Krin (ed.), Jazz Among the Discourses, Durham, Duke University Press, 1995, p. 31-56.

23. DEVEAUX, Scott, The Birth of Bebop: A Social and Musical History, Berkeley, University of California Press, 1997.

24. LOPES, Paul, The Rise of a Jazz Art World, Cambridge, Cambridge University Press, 2002.

25. DEVEAUX, Scott, The Birth of Bebop: A Social and Musical History, Berkeley, University of California Press, 1997.

26. ANDREWS, John, "What bebop meant to jazz history", in World Socialist Web Site, 61, 1993, http://pubs.socialistreviewindex.or..., Accessed 6/14/10, p. 2.

27. Interview with LF, November 8, 2003.

28. Interview with $\mathrm{CD}$.

29. Interview with $\mathrm{CP}$.

30. Interview with LF.

31. GENNARI, John, "Jazz criticism: Its development and ideologies”, in Black American Literature Forum, 25, No 3, 1991, p. 449-523.

32. LOPES, Paul, The Rise of a Jazz Art World, Cambridge, Cambridge University Press, 2002.

33. DEVEAUX, Scott, The Birth of Bebop: A Social and Musical History, Berkeley, University of California Press, 1997.

34. DANNEFER, Dale, “Freedom isn't free: Power, alienation and the consequences of action", in BRANDTSTADTER, Jochen, LERNER, Richard M.(ed.), Action and Self-development: Theory and Research Through the Life Span, Thousand Oaks, Sage, 1999, p. 105-132.

35. Interview with $\mathrm{CP}$.

36. Interview with $\mathrm{CD}$.

37. REDDICK, Lawrence D., "Book review: Inside be-bop”, Phylon (1940-1956), 11, N¹, 1950, p. 99.

38. PORTER, Eric, What Is This Thing Called Jazz?, Los Angeles, University of California Press, 2002.

39. DAVIS, Francis, Outcats: Jazz Composers, Instrumentalists, and Singers, New York, Oxford University Press, 1990, p. 92.

40. OWENS, Thomas, Bebop: The Music and Its Players, New York, Oxford University Press, 1995.

41. STEARNS, Marshall Winslow, “Rebop, bebop, and bop", in Harper's, 200, 1950, p. 89-96, p. 92.

42. GITLER, Ira, Swing to Bop: An Oral History of the Transition in Jazz in the 1940's, New York, Oxford University Press, 1985, p. 232.

43. LOPES, Paul, The Rise of a Jazz Art World, Cambridge, Cambridge University Press, 2002.

44. DEVEAUX, Scott, The Birth of Bebop: A Social and Musical History, Berkeley, University of California Press, 1997. 
45. TOWNSEND, Peter, Jazz in American Culture, Jackson, University Press of Mississippi, 2000.

46. DALFIUME, Richard M., "The forgotten years of the negro revolution", in SCHEINER, Seth M., EDELSTEIN, Tilden G. (ed.), The Black Americans: Interpretive Readings, New York, Holt, Rinehart and Winston, 1971, p. 232.

47. HARVEY, Mark S., "Jazz and modernism: Changing conceptions of innovation and tradition", in BUCKNER, Reginald T., WEILAND, Steven (ed.), Jazz in Mind: Essay on the History and Meanings of Jazz, Detroit, Wayne State University Press, 1991, p. 136.

48. DEVEAUX, Scott, The Birth of Bebop: A Social and Musical History, Berkeley, University of California Press, 1997.

49. BARAKA, Amiri, "Jazz and the white critic", in WALSER, Robert (ed.), Keeping Time: Readings in Jazz History, New York, Oxford University Press, 1999, p. 255-261.

50. STEARNS, Marshall Winslow, “Rebop, bebop, and bop”, in Harper's, 200, 1950, p. 96.

51. Interview with $C D$.

52. "How Deaf Can You Get?", in Time, 51, 1948, p. 74.

53. Interview with RS, November 6, 2003.

54. FEATHER, Leonard, Inside Jazz, New York, Da Capo Press, 1977.

55. Interview with LF.

56. CHAROENYING, Timothy, "Jazz at the Crossroads", in The Atlantic Online, 2003, http:// www.theatlantic.com/unbound/..., accessed 9/30/08.

57. Interview with $\mathrm{CD}$.

58. Ibid.

59. Interview with $\mathrm{CP}$.

60. Interview with $\mathrm{CD}$.

61. Interview with $\mathrm{CP}$.

62. STEARNS, Marshall Winslow, “Rebop, bebop, and bop”, in Harper's, 200, 1950, p. 93.

63. LOTT, Eric, "Double V, Double-Time: Bebop's politics of style”, in Callaloo, 36, 1988, p. 597-605.

64. LOPES, Paul, The Rise of a Jazz Art World, Cambridge, Cambridge University Press, 2002.

65. Interview with $\mathrm{CD}$.

66. Ibid.

67. DEVEAUX, Scott, The Birth of Bebop: A Social and Musical History, Berkeley, University of California Press, 1997.

68. LOPES, Paul, The Rise of a Jazz Art World, Cambridge, Cambridge University Press, 2002, p. 198.

69. GITLER, Ira, Swing to Bop: An Oral History of the Transition in Jazz in the 1940's, New York, Oxford University Press, 1985, p. 233.

70. TOWNSEND, Peter, Jazz in American Culture, Jackson, University Press of Mississippi, 2000.

71. LEES, Gene, The Leader of the Band: The Life of Woody Herman, New York, Oxford University Press, 1995.

72. DEVEAUX, Scott, The Birth of Bebop: A Social and Musical History, Berkeley, University of California Press, 1997.

73. Interview with LF.

74. Interview with $\mathrm{CP}$.

75. Ibid.

76. Interview with LF.

77. GITLER, Ira, Swing to Bop: An Oral History of the Transition in Jazz in the 1940's, New York, Oxford University Press, 1985; PORTER, Eric, What is This Thing Called Jazz?, Los Angeles, University of California Press, 2002; and BOYER, R., "Profiles: Bop", in The New Yorker, 24, 1948, p. 28-32.

78. TOWNSEND, Peter, Jazz in American Culture, Jackson, University Press of Mississippi, 2000.

79. DEVEAUX, Scott, The Birth of Bebop: A Social and Musical History, Berkeley, University of California Press, 1997. 
80. GITLER, Ira, Swing to Bop: An Oral History of the Transition in Jazz in the 1940's, New York, Oxford University Press, 1985, p. 216.

81. STEARNS, Marshall W., "Rebop, bebop, and bop”, in Harper's, 200, 1950, p. 94.

82. LEES, Gene, Leader of the Band: The Life of Woody Herman, New York, Oxford University Press, 1995 , p. 85.

83. FEATHER, Leonard, Inside Jazz, New York, Da Capo Press, 1977.

84. OWENS, Thomas, Bebop: The Music and Its Players, New York, Oxford University Press, 1995.

85. GITLER, Ira, Swing to Bop: An Oral History of the Transition in Jazz in the 1940's, New York, Oxford University Press, 1985, p. 234.

86. Ibid, p. 207.

87. Ibid, p. 212.

88. Ibid, p. 249.

89. Interview with $\mathrm{CP}$.

\section{ABSTRACTS}

This paper examines the movements in jazz in the 1930's and 1940's, and centers on the question of awareness regarding the emergence of bebop out of the Swing Era; the social, musical, and economic realities of the time period; and how these issues relate to concepts in modernism. The research includes interviews completed with jazz practitioners who worked during the time period under investigation supplemented with critical literature. Key constructs that emerged included processes of institutionalization, issues of revolution versus evolution in jazz, the role of media in jazz reception, and issues of artistic autonomy and commodification.

Cet article étudie les mouvements qui agitent le jazz au cours des années 1930 et 1940. Il se concentre sur les questions de prise de conscience du jazz face à l'émergence du bebop à l'issue de l'ère Swing. Sont également abordées les réalités sociales, musicales et économiques, dans leur rapport au modernisme. Cette étude s'appuie sur des entretiens réalisés avec des musiciens de jazz ayant travaillé durant cette période, ainsi que sur la littérature afférente. Il se confronte aux processus d'institutionnalisation, aux problèmes de révolution ou d'évolution du jazz, au rôle des médias au sein des processus de réception, ainsi qu'aux questions d'autonomie artistique et de commercialisation.

\section{INDEX}

Keywords: 1930s, 1940s, artistic autonomy, commodification, institutionalization, media, modernism, bebop, jazz, swing

Mots-clés: années 1930, années 1940, autonomie artistique, commercialisation, institutionnalisation, médias, modernisme, bebop, jazz, swing 


\section{AUTHOR}

\section{WILLIAM M. DABBACK}

Dr. William Dabback joined the music faculty at James Madison University in 2005, where he teaches courses in instrumental methods, instrumental techniques and conducting. He directs the Harrisonburg New Horizons Band, which he formed in 2008 and plays solo cornet in the Massanutten Brass, the Shenandoah Valley's resident British-style brass band. He has presented papers and workshops on music, teaching and learning at conferences in the United States, Canada and Europe. 